\title{
Indian Tribal Educational System for the Santal Children of Mayurbhanj District of Odisha: A Psychosocial Analysis
}

\author{
Singo Hembram ${ }^{1}$, Dr. Ratnakar Mohapatra ${ }^{2}$ \\ 1 RGNF Ph.D. Research Scholar, Department of History, KIIT, Deemed to be University, Bhubaneswar, PIN-751024, \\ Odisha, India. Email: singo.hembram@gmail.com \\ 2 Assistant Professor, Department of History, KISS, Deemed to be University, Bhubaneswar, PIN-751024, Odisha, India \\ Emil: ratnakarmohapatra2017@gmail.com
}

\begin{abstract}
The study on educational system of the Santals of Mayurbhanj is an interesting aspect of the tribal education of Odisha in Eastern India. Santals are the the largest number of people among the total tribal population of Odisha. Education of the tribal communities /societies has helped in preservation of social structure and goal achievement. The Santals are largely residing in the Mayurbhanj district of Odisha. The development of education of the Santals of Mayurbhanj district is the main part of the tribal educational system of the state of Odisha. Odisha has possessed a distinct place in tribal history of India and it is the home of a number of different types of tribes. Different developmental programmes / schemes for education have been implemented through the Governments and Non Government agencies for the educational improvement of the tribal children of Odisha in general and Santal children in particular. On the basis of field study made by the earlier scholars including the present authors, the people of Santal tribe/society are mostly residing in the Mayurbhanj district of Odisha. In fact, most of the tribes of Odisha in Eastern India have no written languages, but in case of Santala tribe, it has a written language with a specific 'Ol Chiki' script for the use of its own people. The Santal children of Mayurbhanj district are more interested in modern education in comparison to other tribal children of Odisha. At present the educated people of Santal tribe of Mayurbhanj have been able to organize their socio-cultural associations for preservation of their traditional culture. The aim of this paper is to focus on educational system for the Santal children of Mayurbhanj district of Odisha along with to highlight their receptive minds for receiving modern education for their moral as well as physical developments for entry into the main stream of the present / modern society. Methodologically, both the primary and secondary sources have been carefully utilised in the present article.
\end{abstract}

Keywords:

Indian, tribal, educational, system, Santals, children, Mayurbhanj, Odisha.

Article Received: 18 October 2020, Revised: 3 November 2020, Accepted: 24 December 2020

\section{Introduction}

Usually, Indian traditional educational system was chiefly the worldview of the tribal people. Socially and educationally, the Scheduled Tribes (ST's) are among the most disadvantaged groups of Odisha in Eastern India. After Independence in 1947, it was chosen to allow an exceptional favorable position to in reverse gatherings, planned as booked clans just as booked stations. The legislative issues of positive separation inferred that people having a place with these gatherings were saved seats in instructive establishments and occupations in the public area. The explanation behind such sure separation was that the station framework had favored high position individuals to an unreasonable degree previously. To start with, this approach has been is as yet helpful to battle monetary abuse and persecution of ancestral individuals in India, second the affirmation of the class attributed to the gatherings concern the option to support a free culture, which is not the same as the dominant part. Obviously, any social element might be viewed as a development (Barth. 1969, Anderson,1989) however, on account of the Santals, the possibility of nativeness has assisted them with argueing their requests for social improvement and schooling.

Indeed, education is the key for socioeconomic development of human being and an input issue for decisive of the national development. Odisha was an educationally backward state of India till the advent of the planning in 1950-1951 AD. Modern education is 
being imposed on the tribal people, which most often does not refer to the tribal culture to which they are acquainted with since generation is not properly accepted by them and thus in many cases , tribal take it negatively (ADIVASI, Volume-50, June\& December,2010, p.131). The level of literacy is very low among the Indian tribal society. As per the 2001 Indian Census, the populace of the tribal communities of India is $8.27 \%$ of the total people. In India, there are as many as 689 Scheduled Tribes speaking in 105 languages along with 225 speaking supplementary languages (Mohanta, 2015, p.18). Odisha is regarded as the homeland of a number of different types of tribes. Odisha is aptly considered as the land of a number of different types of Scheduled Tribes numbering sixty two. The Santal people are the majority in numbers among the whole tribal population of the Mayurbhanj district, which was the largest and wealthiest feudatory state of Odisah in Eastern India.

The district of Mayurbhanj of Odisha lies between $21^{\circ} 17^{\prime}$ and $22^{\circ} 3^{\prime}$ ' north latitude and between $85^{\circ} 40^{\prime}$ and $87^{\circ} 10^{\prime}$ east longitude (Senapati and Sahu, 1967, p.2). The Mayurbhanj district is surrounded on the northern side in the Singbhum border of the Jharkhand state and Mindnapur of West Bengal, on the southern side by the Balasore as well as Keonjhar districts of Odisha, in the eastern side by the Mindnapur district as well as Balasore District, on the western side by the districts of Keonjhar as well as Singhbhum ( Karua, 2014, p.4). In fact, Mayurbhanja is a tribal dominated district of Odisha and as many as 45 Scheduled Tribes were inhabiting in this district as per 1961 Census. At present 55 Scheduled tribes are noticed in the district of Mayurbhanj (Tribes in Odisha, 2015 and Karua, 2014, p.1). Out of the total tribal population of Mayurbhanj, Santals are the largest among them by considering its people. The educational status of Santals of Mayurbhanj is an interesting aspect of the whole tribal educational system of India. The present article attempts to focus on the educational system and various schemes introduced by the Governments for the educational upliftment of the children of Santal society of the Mayurbhanj district of Northern Odisha in East India.

\section{Methodology}

The data collected from both the primary and secondary sources are critically analysed and used in the writing of the article. The primary data have been collected from Gazetteers, folk lore, folk tale, and unpublished thesis, the practical observation, public opinions, hearsay accounts through the interview methods during the period of experimental field survey by the principal author. The field study, personal interview, schedules and taking photographs are made by the authors. The general field survey has been undertaken for the collection of data relating to the educational systems for the Santal children of Mayurbhanj district of Odisha in Eastern India. The secondary data relating to the present article are Gazetteers, Books, Magazines, Reviews, Journals, Periodicals, Proceedings, Records, Reports, and published as well as un published theses.

\section{Discussion And Result Analysis}

\section{Educational System of India}

Importance of education in India has been realized since time immemorial, particularly in Vedic period. It is found that in mediaeval period tolls were established by the Brahmin for learning on the sacred aspect, philosophy, literature and science by Brahmin teachers. Another institutions like pathsala was for giving the elementary knowledge to the lower caste community members (Mohanta, 2015, p.22). During the British period, the government took initiatives in educational department of India. Therefore, Sanskrit schools and Madarasa were opened in few areas for producing court officials (Mohanta, 2015, p.22). Then the British Government had introduced the English education in 1835 AD by advice of Lord Macaulay. At that time primary education was not compulsory. It was controlled by local bodies and neglected the tribal people in education (Mohanta, 2015, p.22). Therefore 
education of tribal was neglected before independence. The earliest efforts for tribal education were made by the foreign missionaries. Hunter commission report (1882) started that efforts of tribal education seems to be credible as most of the Christian tribes show very high literacy rate e.g. the mezzos of Mizoram. In this report he also recommended for expansion of the primary education, during the pre-independence period British ruler adopted a strategy of seclusion and maintained status quo of tribes, on the whole to follow the policy of laissez fair (Mohanta, 2015, p.23). Initial efforts by the Indian were started around 1940. Similar efforts were made by some of the Indian voluntary organizations. The Government of India has made certain constitutional provision for the tribals. The article 45 is provided for free along with necessary education for children. Never the less, the article 46 is highly significant to the scheduled tribes as well as other poor sections of India (Mohanta, 2015 , p.23). For spreading education among the scheduled tribes, a number of schemes of incentives have been started by central and states governments. These are free education, scholarship, residential / hostel facilities, Ashram schools, free books and stationary reservation of seats in learning institution in proportion to their population (Mohanta, 2015, p.24).

The Indian Education Commission Report (1964-66), which is commonly referred to as the Kothari Commission Report. Its Chairman D.S. Kothary has stated that "it is necessary to pay special attention to the education of the children from the backward classes, the scheduled tribes, de-notified communities and a few nomadic and semi-nomadic groups"(Shastry, 2010, p.13).The Commission on Scheduled Areas and Scheduled Tribes had critically examined the various facets of tribal education and had provided certain cogent suggestions. The Kothari Commission endorsed the Dhebar Commission approach. The enrolment of Tribal children was much lower in Odisha. On the basis of Kothari Commission, the Tribal Girl's education was emphasized as she was at the rock of bottom of the educational spectrum (Shastry, 2010, p.14). The school calendar should be turned into to the tribal lifestyle. The development of secondary education was a major concern. The Ashram School system is found to be established by the Government of Odisha for developing education among the tribal children. The educational system for the Santal children of Mayurbhanj district is briefly discussed below.

\subsection{Education of the Santals of Mayurbhanj District of Odisha}

The Santals are one of the largest tribal groups of the northern Odisha in India. They are mainly found in the district of Keonjhar, Balesore, Sundargarh, Dhenkanal and Mayurbhanj in the state of Odisha (Padhi, 2009, p.138). Santals also inhabit in the bordering provinces of Jharkhand, Bihar, West Bengal and Assam (Murmu \& Dash, Vol.52, No.1 \& 2, June \& December 2012. p.86). In fact, the people of Santal tribe speak an independent language known as 'Santali'. Santals belong to Munda group, language of the AustroAsiatic family (Troisi, 2000, p.26). The Scheduled Tribes are reported in 30 States / UTs and the number of separate ethnic groups, etc. informed as Scheduled Tribes is seven hundred five (Statistical Profile Of Scheduled Tribes In India 2013). Out of sixty-two tribes seen in Odisha, fifty-five are found in the district of Mayurbhanj (Karua, 2014, p.1). As per the Census of 2011, the total populace of Odisha is $41,974,218$. Out of which 34,970 , 562 number of people living in coastal rural areas. The numerical strength of the male population is $21,212,136$ and the female population is 20,762,082 (www. Planningcommission.nic.in). Out of 25, 19, 738 number people of Mayurbhanj, the number of male populations is 12,56, 213 and the number of female populations is $12,63,525$ (Census of India, 2011, p.18). It covers an area of 10418 square kilometres and consisting of 3970 villages. The Santals from the Santal tribe of Odisha is 8,94, 764 (Karua, op. cit., 2014, p.1). Out of the total, 6,38,104 number Santals are residing in Mayurbhanj district of Odisha (Ota \&Mohanty, eds., 2015, p.290). 
In fact, the instruction is the endurance of the relative multitude of networks of any country. At the point when one thinks about the high rate of proficiency in the created nations, one is enticed to reason that an essential for social, financial just as political improvement is the destruction of ignorance and the universalization of education (Saren, July 2013, p.32). Owing to the impact of globalization, the Santals have been acknowledged and fill of the need of better schooling for their youngsters and family members (Dey, June-2015, p.40).Tribal training was not an alternate sort of instruction, rather it was to suit the exceptional necessities and desires of the ancestral individuals who are in various phases of development (Chowdhury, 2013, p.107). All the tribes of Odisha have their conventional instructive foundations, which are usually known as youth dormitories (Mishra,2011, p.214). The customary instructive establishment and happy making are the primary highlights of the Santal society of northern Odisha, Both male and female used to go to it. Also, it is where the town gathering meets. In the Akhala the Santal senior individuals from the local area train the youngsters in various fields of asset culture the board. The seniors of Santal tribe / society control the youngsters to arise as capable individuals from the society (Mishra, 2011, p.215). It is here that the small kids become familiar with the craftsmanship and specialty to procure their occupation. The Akhala effectively educates the more youthful age about the classic stories, fantasy, legends, questions, sayings, strict stylized solutions, ethos, belief systems, ethics, standards and estimations of the local area The Akhala is a preparation ground for accepting directions in different fields, for example, strict, financial just as political. It gives a setting where small kids learn by imitation (Mishra, 2011, p.215). The Akhala has extraordinary probability even today to arise as a trot for non-formal schooling as well as for formal training on the off chance that it is perceived by instructive specialists and revitalized (Mishra, 2011, p.215).
Education is the weapon to change the society. Education not just aides in working up person's character, character and insight yet in addition his beneficial limit and his capacity to play out a lot of work all the more effectively. It additionally uncovers that in essential training the brews rate is higher than the females. This is on the grounds that, with the constrained asset they like to instruct just for their male kids. The Santal people rely upon the Government run instruction organization, Due to some reasons number of understudies drops out even at the essential level from instruction. In addition, after the beginning of adolescence, the customary and moderate guardians like to hold their little girls at home and organize marriage as opposed to sending them to class. Initially, most of the Santal young ladies don't want go for advanced education since they study advanced learning educational plan is troublesome so this is smarter to remain at home to help family unit works ( Tudu, and Mohapatra, 2020, Vol. No. 7,Issue-7,p.851). Now-a-days Government of India as well as Odisha have taken so many developmental programmes for advancement of training among the Santals of Odisha including Mayurbhanj. The Schools provide everything to the Santal children like dresses and other materials for their education. Now, the Santals are attentive to offer new education to their children.

\subsection{Educational Schemes for the Santal Children of Mayurbhanj}

Formal schools entered late in the tribal societies of Odisha in Eastern India. The schools were established to bring about changes in the life of the tribal people so that they could fit themselves into the modern society (Ota, Mohanty, June \& December 2010, p.3). A word about Santal education and its relevance for economic growth and development ( Padhy, 1998, p. 90 ). Educationally, Santals were generally illiterate. But the picture has been observed to take different in this present century to some extent. Awareness regarding education has been observed since two generations of the Santal community to a range. Parents are sending their children to 
Anganwadi centres and schools. Most fascinatingly in this region Santal girls are also encouraged for higher education. Improvement in literacy levels has positively affected in changing the economic and socio-cultural life of the Santals as well as this will restrict them to be exploited in the hands of other people. Government as well as non-governmental sectors have immensely contributed in high reaching the literacy and creating awareness regarding the need for education. The advancement programs for development of instructive level along with reservation strategy in various kinds of occupation by the public authority have caused the Santal youth to change the occupation design for improvement of their living. The Ministry of Social Justice and Empowerment as well as Ministry of Tribal Affairs of India have taken a few measures for monetary turn of events. These are: ITDP, LAMPS and AMSY under NSTFDC (income generation scheme). The Development programmes act as the accelerating force in the producing an opportunity of higher education and better employment, which is grabbed by the present generation Santal of this area (Paul, and Gupta, 2015, p.10)

During post-independence era since 1951, the government of Odisha started a number of formal schools for the tribal children. The government certainly provided several facilities (Ota and Mohanty, 2010, p.3). Despite the fact that Article 45 of the Directive Principles of State Policy manages the arrangement of free and obligatory instruction for the Constitution, for nothing and necessary schooling for all youngsters, until they complete the age of 14 years, really significant plans and projects were started exclusively after NPE was planned in 1986 and the POA was set up in 1992. Regardless, the critical tasks executed by the Department of Education include: Prarambic Shiksha Kosh (PSK), Sarva Shiksha Abhiyan ( SSA), District Primary Education Programs (DPEP), Jan Shikshan Sansthan (JSS), Education Guarantee Scheme (EGS), Alternative and Innovative Education (AIE), National Program for Education of Girls at Elementary Level (NPEGEL), National Institute of Open Schooling (NIOS), Mahila Samakhya, Education for Women's Equality, National Programs of Nutritional Support to Primary Education which is predominantly known as Mid-Day-Meals plot (it is a program of the Ministry of Consumer Affairs, Food and Public Distribution Department yet realized by the Department of Education), Kasturba Gandhi Balika Vidyalaya (KGBV, etc and the huge informative projects of the Ministry of Tribal Affairs that understanding requirement for the Scheduled Tribes fuses: Book Bank Scheme for the ST Students, Construction of Hostels for ST Girls and young fellows, game plan of Amenities in Tribal Hostels, Construction of Educational Complex in Low Literacy Tribal Areas, Pre and Post Matric Scholarship for ST understudies including invalidation of instructive cost, Provision of Free School Uniform, Provision of Free Study Materials, National Overseas Scholarship for ST Students, Distribution of Bicycles to ST Girls understudies, Introduction of Teaching in Tribal Languages in Primary Schools.

Introduction of coaching allowance to teachers gngaged on contractual basis in High School / Girls High Schools, Computer Education in High School / Girls High Schools (Ota, \& Mohanty, eds., 2009, pp.52-53). Rajiv Gandhi National Fellowships (RGNF) for M. Phil. And Ph. D. Courses (S. K. Paul \& A. Gupta, 2015, p.10). Under this Scheme, the tribal students are provided with fellowships for pursing research studies in higher education, etc. (Andrabi, 2013, p.2).

In Statistical information the instructive requirements of Santals in Mayurbhanj District were served by 2941 grade schools, 795 center schools, 437 auxiliary schools and 64 universities for general training. Ashram Schools including Kanya Ashrams have been set up to take into account the necessities of the ancestral understudies. They are generally private in nature. Another inventive foundation to give training to ancestral youngsters at the essential level are Seva Ashrams both private and non-private. A striking 
advance taken by ST and SC Development Department to build enrolment of ancestral understudies and lessening dropout rates among them at the essential level has been the foundation of 40 seat Primary School Hostels (PSH)in every one of 1548 Gram Panchayats in Scheduled Areas of the state. The Department has likewise taken exceptional activities for the foundation of model Tribal Schools in the example of Novadaya Vidyalaya with the end goal of making focuses of greatness in ancestral training. In this study area one such School is found to be established at Salbani of Betanati block of Mayurbhanj District( Mishra, 2011, p. 212).

The concept of Tribal Sub-Plan emerged out of the recommendations of the Task force and guidelines were issued by the Planning Commission as well as the Ministry of Home Affairs, New Delhi for preparation of Sub-Plan for tribal regions. The tribal Sub-Plan of Odisha covers the areas of Koraput, Mayurbhanj and Sundargarh districts (TEOCE: A State Paper, 1994, pp.7-8). In the Modified Area Development Approach (MADA) pockets both individual benefits-oriented scheme and community profitoriented programmes for welfare of the tribals are under implementation. In addition to the educational development of the tribal people covered under the tribal sub-plan areas. It is felt essential to go for a concurrent exercise so that the inadequacies and short comings of tribal education in the Modified Area Development Approach (MADA) pockets are evolved.

On the basis of central Government's tribal schemes, Integrated Tribal Development Agency ( I.T.D.A) was set up at Baripada, Karanjia, Rairangpur and also another I.T.D.A was found to be set up at Kaptipada Blocks of Mayurbhanj district. National Policy on Education 1986 with modifications was undertaken in 1992. Some of measures were taken in the Hill Kharia areas as well as other tribal zones of Mayurbhanj are viz.1. Primary schools are found established in the different local areas of the Santal community. 2. School buildings have been built in the different places of Jashipur, Karanjia , Morada, Suliapada,
Udala, Badashahi, Khunta, Shama Khunta, Baripada, Thakurmuda, Rsgobindpur, Bangirposhi,, Rairangpur, Kaptipada, etc. Blocks of the Mayubhanj district of Odisha.

The Government of India has provided different types of schools like Anganwari, Nonformal and Adult education centers in the Santal areas of Mayurbhanj district. Sarva Siksha Abhiyan was launched in India since 2003. It was also implemented in the tribal areas of Odisha. DPEP was the foundation of the SSA and the scheme was initiated in 1994 and the prime objective of this was to provide all children with access to primary education within formal system, which was started during 1079-80. The Mid-DayMeals Scheme was started in the year of 1995. Kasturba Gandhi Balika Vidyalaya (KGBV), the residential upper primary schools for girls students of ST and SC communities are found established in the different places of Bahalda, Bijatala, Bisoi, Jamda, Badasahi, Jashipur,Kushimi, Rairangpur, Kaptipada, Khunta, Shama Khunta, Baripada, Thakurmuda Blocks of Mayurbhanj district. National Programme of Education for Girls at Elementary Level (NPEGEL) were also started by the Government of India in tribal areas of Mayurbhanj. The Ministry of Tribal Affairs provide financial assistance to construct different categories of educational institutions in the tribal areas of all states including Odisha. In this way, many changes are found in the tribal children's education system of India.

\subsection{Santal Children at KISS}

Really, education reforms the process through which students can learn something. It is categorized under Primary or Elementary, Secondary and Higher, Post Higher Secondary. There are various phases attached to the term education take Formal, Non-formal ,Vocational, Adult, etc. Indigenous education as somehow similar to the expression we use as tribal education. On the basis of the National Policy on Education (NPE), emphasis has been giving on opening of Primary schools in tribal areas. Despite pragmatic policies of the government, the tribal children have been lagging behind the general 
children and reasons can be categorized as internal and external. While the inside requirements allude to issues identified with educational system, substance, vehicle of guidance, instructional method, scholarly oversight and educator understudy connection, the outer limitations are identified with issues and challenges at levels of strategy, arranging, execution and organization (Patnaik, 2010, pp.104-105). With this backdrop, education to be imparted to the tribal children appears to be stupendous task in Odisha with 62 tribes including 13(thirteen) Primitive Tribal Groups constituting almost $23 \%$ of the total population(Patnaik, 2010, pp.104-105).

Really, the tribals of Odisha including Santals speak as many languages and dialects and it becomes difficult to teach them in their own dialects. In my practical field observation, it can be said that there is need for link language to teach the Santal children of our state. With the different beneficiary objectives for the tribal children including Santal community, Kalinga Institute of Social Sciences (KISS) started with only 125 Tribal children in the year 1993, has now turned into the largest residential Institute of Asia for the tribal children. All the tribal children of Odisha and outside state are being admitted in to different classes for getting education at KISS campus, Bhubaneswar. Here all the tribal children are provided with education, food, accommodation, health care, dress and all basic facilities of life absolutely free. Initially KISS faced a lot of problems in pursuing the tribal parents to send their children to school, so that they would be aware of exploitation and other necessary evils (Patnaik, 2010, pp.104-105). Initially, it was very difficult on the part of Hon'ble Founder (Prof. A. Samanta) of KISS as well as the entire team of KISS to motivate the parents living in the tribal districts of Odisha.

Due to strong determination and dedication for educating the tribal children, now the KISS became the largest residential institute of India exclusively for 27,000 tribal children. The KISS has become a perfect center of learning for the poorest of the poor sections of the tribal society having a focus on sustainable livelihood, education and scope for all round development (Patnaik, 2010, pp.104-105).KISS is providing different types of education/ opportunities for the social and educational development of tribal children. This institute is determined to provide maximum exposure to the tribal children by giving them opportunities to excel in their skills through education, extracurricular training and several vocational training courses, like preparation of saline, tailoring, fishery, handicrafts, etc. Now, KISS is moving towards to role model of Santiniketana. By keeping the children in the midst of natural surroundings and by giving the children of nature turned KISS into a unique institution, which is named as a Second Santiniketana by Padma Bibhusana Magsaysay Award Winner Mahasweta Devi (Patnaik, 2010, p.105). Really, KISS is gardening or growing vegetables or any other vocational training for a sustainable employment, children of KISS do it with ease. KISS serves a dual purpose, because with those activities the children remain connected to nature and the environment while vocational training instills confidence in them. The novel scheme to be paid for their work is like "earning while still learning" makes KISS unique.

The tribal children are provided with the facilities to pursue their studies from Kindergarten to Post Graduation ( $\mathrm{KG}$ to $\mathrm{PG}$ ) level at the Kalinga Institute of Social Sciences since 1993. Year after year the children, appearing the High School certificate examination are coming with a hundred percent pass result against the state average of 54\% (Patnaik, 2010, p.106). Really, KISS has successfully arrested the problem of dropout without even a single case noticed as yet. In the National Science Congress and National Children Science Congress, the students of KISS are making their presence felt through their experiments and models displayed there. For the betterment of tribal students, KIIT has come forward with a provision of 5\% seats in all its wings reserved for the children of KISS to pursue higher studies in Engineering, Law, and Medical Sciences. The problems of dropout of tribal 
children including Santal children are being checked completely. The papers, pens, books and other teaching aids are being provided by KISS to the tribal children, so they do not face any difficulty in getting quality education, students and teachers are staying together in campus.

Besides the study, even in the sports, the KISS Rugby Team gave a starting performance at the world under 14 Rugby Championship in London. They defeated the tough South African team by 19-5 goals (Patnaik, 2010, p.107). It is not the Rugby alone, the tribal children of KISS have been showing remarkable performances in other state level sports including football, volley ball, cricket, etc. The abundance of talent of the tribal children which remained untapped till date now find a true and meaningful exposure through the efforts of KISS. Such types of scopes give a golden opportunity to the tribal children, for which the children of different tribal communities including Satal of Odisha can excel in everything.

Statistics available with the government and the facts gleaned from the Census report of 2001 leave no doubt whatsoever that the tribals in Odisha are living in most deplorable state without adequate food and nourishment(Patnaik, 2010, p.107).The Santals of Mayurbhanj and other places of Odisha are completely in neglected condition. Acute poverty has reminded instrumental in keeping them illiterate and ignorant of the progress around them. At this state of their deprivation, they are easily lured to unlawful activities sometimes without knowing the consequences thereof and sometimes without finding any alternative source to develop and illustrate their skills for a sustainable livelihood. Kalinga Institute of Social Sciences to some extent has been successful in reversing the trend. By the novel experiment, KISS reduced the dropout rate, fostered the talents to instill confidence in the children to excel in education, vocational training, games and sports and bringing lauries for the state and the country (Patnaik, 2010, p.108). No doubt, KISS is working at best for the educational development of tribals. As per the report of KISS, a number of students of Santal tribe have admitted into the KISS, Bhubaneswar.The major objective behind the conceptualization of the KISS is to empower the indigenous children through free holistic and quality education (KISS Annual Report 20152016, p.22). Really, KISS has many ambitious plans up to its sheaths. A modest attempt has already made by the KISS in providing a level playing field for the tribal children of Santal community and other tribal groups of Odisha. The untiring efforts of KISS team will succeed in creating awareness amongst all the stake holders, civil societies to look at the problem of the tribals and work for the empowerment of them through education (KISS Annual Report 2015-2016, p.22). The tribal children of KISS have earned recognition in academics, vocational capabilities and global recognition in sports. Professor Achyuta Samanta, the Honourable Founder of KISS is of the view that giving education to tribal children is like giving vision to a visuallyimpaired person. It is really an ideal view of a good philanthropist.

\subsection{Invention of Ol Chiki Script for Santal Children}

At present, hereditary social affairs in India ensure the choice to move towards preparing through their local language. Various solicitations concern social lifestyle as the Santals who love their own divinities (bongas) have been a portion of the time alloted, without needing to, as Hindus in the Census of 1981or as animists, which routinely proposes without religion. After the revision of the States on a semantic reason in postIndependent India, a critical issue remained concerning the status of minority tongues inside the overhauled states. The tongues are organized in a hierarchy of genuine status, we find at the top Hindi and English, considered as obvious vernaculars at the public level. At the accompanying level, we find the common tongues, for instance, Bengali or Odia. At the lower level are the tongues which are not seen as evident vernaculars (Tambslyche, 2013, pp.5-6).

The Santals have been more determined of their own language than large numbers of the 
others whom they are racially associated. To keep up the personality of the locale and to reinforce the bases of ancestral fortitude, the Santals have built up an unmistakable content "Ol-Chiki' for their language. Pandit Raghunath Murmu the profound head of the Santals who is known as the Guru Gomkey ( Chhatia, Vol.XXVI, 2013, p.140). He was the most convincing otherworldly pioneer and image of socio-social solidarity among the Santals (Chhatia,Vol.XXVI, 2013, p.140). Pandit Raghunath Murmu was brought into the world upon the arrival of Baisakhi Purnima for example fifth May,1905 in a Santal village called Dandabose (Dahardihi) in the current region of Mayurbhanj in Odisha, he developed "Ol-Chiki Script" in 1925 (Karua, 2014, p.249). Exactly when Raghunath Murmu was packing in Gambharia L.P. School (1912-1913), most importantly it was astoundingly difficult for him to grasp the Odia vehicle of training.

While Raghunath was working as an apprentice in Baripada Power House, his innovative talent surprised Wellwood, the State Chief Engineer. Murmu pointed out certain defects in the blueprints of an installation. His idea of housing new technique for producing and furnishing qualitative carpets attracted the attention of P. K. Sen, Dewan of the State. Murmu was sent to Calcutta for the Industrial Training. On his return he was appointed as an Instructor in the Purna Chandra Industrial Institute, Baripada in 1933. He sought a transfer to the near place and was posted as the Headmaster of Bodamtolia Model School. There, he took a very keen interest in discovering the $\mathrm{Ol}$ Chiki Script for writing Santali (Karua, 2014, p. 249).

According to Pt. Raghunath Murmu 'OL' connotes, "without making any steady, simply looking through eyes by drawing in the picture of things mind" and "Chiki" generally prefers to pictorial depiction." The OL-CHIKI content, in any case called 'OlChemet' (learning of creating, in Santali, 'Ol' means making and 'Cemet' implies learning). Ol-Chiki has 30 letters, the kinds of which are required to gather regular shapes. These consolidate six vowels (Raha Alang) along with twenty-four consonants (Keched Alang). Ol-Chiki has fundamental diacritics, and the mix of diacritic 'Mu Tudah' and 'Gahla Tudah' offers climb to another diacritic, called 'Mu-GuhlaTudah'.

As referenced before, Murmu has composed a good numbers of books in Ol CHIKI content, covering conventional tunes, novel, short stories, strict messages, fantasy and legends, book on Santali language, essential books for learning OL CHIKI, books on incredible people in the Santal tribe / community (Mohanta, 2015. p.226 and Murmu and Das, 2012, p.87). Most popular books of Pt. R. Murmu are dramas like Bidu Chadan (Odia-1942, Bengali-1947), Kherwar Veer (Odia-1944, Bengali-1952), Dalegedhon (Santali-1966). Hital part-I and II (Unpublished) contain the songs in praise of the creator. Bhakhen contains songs of invocation meant for specific occasion. His other books are Hor Serenj, Njel Jong Lagid Ol, Ol Chemed, Elkha Potob(Arithmatic) in 1966, Pari Itun, Parshi Poha, ParshiOpad, Parshi Gajal, Parshi Panja, Sid-Kanhu, Santal Hul, Lacture Serenj, OlUpurum, Ranal (Grammar), etc. In his writings he has projected the image of the story's heritage of the Santals along with certain predominant socio-cultural issues like drinking of rice-beer, intra-sept marriage, the propitiation of Gods, individual morality and social ethics, etc. (Karua, 2014, p.255). As a versatile genius he has been the most potent spiritual leader. The Mayurbhanj Mahasabha honoured him with the title Guru Gomkey (The great preceptor) for his unparalleled service to the Santal community living in various parts of the country. The Dhumkaria in Ranchi University conferred the D. Liit. Degree on him in 1958 for his outstanding contribution to Adivasi Literature. M.D. Jullias Tigga, the education minister of Bihar called him a great inventor and dramatist. The popular Tribal leader Jaipal Singh called him an Anthropologist and Pundit. C. L. Mukharjee described him as the priest of Santal tribe. Martin Orans (USA) tells him the Spiritual Guru of the Santals. Ranjit Singh Bariah, the exminister of Odisha called him a great orator with charming voice. For his literary contribution, 
Orissa Sahitya Academy has awarded him as the founder of Santali language and inventor in 1978. Jyoti Basu, the then Chief Minister of West Bengal honoured him as Oll Guru at Kendvola village (Purulia) in 1979. As a champion of education, the first Santali School was established by him at Bet Kundari village of Midnapur in February, 1977. He also laid the foundation of a Santal University at Bet Kundaidahi of Jhargram on $21^{\text {st }}$ February, 1977 for the effort of Santal culture and language (Karua, 2014, pp. 255-256).

Looking at the language advancement of Santal tribal neighborhood Bihar, Jharkhand, West Bengal and Odisha, Government of India recalled Santali for the eighth Scheduled of the constitution of India in the year 2003. Considering Multi Lingual Education (MLE) rule, the territory of Odisha has responded distinctly to the solicitations of tribal organizations of Mayurbhanj district and embraced fittingly. Government of Odisha, introduced Ol-Chiki in the school level additionally to associate the language connecting between tribal community and current culture. Under Sarva Shikhya Abhiyan (SSA) program Santali kids are given guidance in their own substance Ol-Chiki. In Mayurbhanj region 100 schools in the year of 2007-08 have accepted OlChiki under Multi Lingual Education (MLE) to allow guidance to the Santal children. This is a piece of the push to rename and reassert their ethno-social character (Sahoo, Vol. No.1 and 2, 2012, p.103).

At present the educated Santals have been able to organize their socio-cultural associations for preservation of their traditional culture. They have also been highly influenced by Hindu culture and are highly assertive. Their progressive outlook is clearly indicated from suggestions offered by the Santal girls (Mishra, B. 2010 , p.72). As indicated by 2001 statistics the all out education pace of the Santals of Odisha including Mayurbhanj locale was $40.46 \%$. Among males it was $55.86 \%$ and among females it was appallingly low at $24.75 \%$ ( Ota, and Mohanty, eds., 2015, p.289).

\section{Conclusion}

It can be concluded from the observation of the present study areas that in early period a few of the boys of Santal society are going to school in spite of long distance of schools from their villages, but in that period, girls' students / children are not interested in study for which they were engaged in household works. Initially, most of the Santal young ladies don't want go for advanced education since they study advanced learning educational plan is troublesome, so this is smarter to remain at home to help family works. Now-a- days, both boys and girls of Santal community / tribe are being encouraged by both the central and state governments educational schemes, for which they are going to school regularly. On the basis of various government schemes, different types of schools are found to be established nearby the Santal villages. For which, now a days girls of the Santal tribe are getting equal status with boys of their own community/ society. Through the ITDA of Baripada, Kaptipada, Karanjia, Rairanpur, different types of educational schemes of Governments are being introduced for the development of education among the Santal children of Mayurbhanj. Now a days , Primary schools, M.E. Schools and High Schools are found to be established in different places of Mayurbhanj district for the spread of education among the Santal children of Mayurbhanj. Kasturba Gandhi Balika Vidyalaya (KGBV), the residential upper primary schools for girls students of ST and SC communities are found to be established in the different places of Bahalda, Bijatala, Bisoi, Jamda, Badasahi, Jashipur, Kushimi, Rairangpur, Kaptipada, Khunta, Shama Khunta, Baripada, Thakurmuda Blocks of Mayurbhanj district. National Programme of Education for Girls at Elementary Level (NPEGEL) were also introduced by the Government of India in the tribal areas of Mayurbhanj. For the spread of education, Kalinga Institute of Social Sciences, Bhubaneswar is providing different types of education / opportunities for the tribal children including the Santal children of Mayurbhanj district. This 
institute is determined to provide education, extracurricular training and several vocational training courses for all the tribal children of Odisha as well as India. By the introduction of various Government Educational schemes, Santals children of Mayurbhanj are admitted into nearby colleges and also at KISS for higher education. Most of the Santal boys and girls of the Mayurbhanj district are interested in modern education of KISS. The minds of Santal children are also receptive for any kinds of education in comparison to other tribal children as known from the survey. Administration of Odisha has presented Ol-Chiki content in school level to connect the language hole between ancestral Santal society and current culture. Now, the educated Santals of Mayurbhanj have been able to organize their socio-cultural relations for preservation of their traditional culture. On the whole, the literacy rate of the children of Santal community / society of the Mayurbhanj district is satisfactory in comparison to other tribal children of Odisha in Eastern India.

\section{Acknowledgement}

We are extremely grateful to Prf. S. Samanta, Prof. H.K. Satapathy, Dr. P. K. Routray, Dr. B. Suna, Dr. I. Naik, Prof. Harihar Panda, Prof. P.K. Nayak, and Prof. Byomakesh Tripathy for their encouragement and valuable suggestions in the course of preparation of this article.

We express our profound reverence to Prof. Achyuta Samanta, the Hon'ble Founder of KISS, Deemed to be University, Bhubaneswar who encouraged us for the writing of such type of article.

\section{References}

[1] Senapati, N. \& Sahu, N. K., eds. (1967). Orissa District Gazetteers Mayarbhanj, Orissa Government Press; Cuttack.

[2] Behura , N. K. (2004). Tribal of Odisha, Schedule Caste and Schedule Tribes Research and Training Institute, Bhubaneswar.
[3] Samal, A.(2001).Tribal Development Administration; Case Study of District in Odisha, ISEC, Nagarbhavi post,Bangalore.

[4] Tribes in Odisha at a Glance Empowering the Tribals of Odisha, (2015). Scheduled Castes \& Scheduled Tribes Research and Training Institute Bhubaneswar, Odisha.

[5] Nayak, U.K. (2004). Mayurbhanj Parichaya (Odia book), Royal publication, Baripada, Mayurbhanj.

[6] Dash , J. (1999). Human Ecology of Forager , Commonwealth Publishers Ansari Road, Darya Ganj, New Delhi.

[7] Bage,M. (1960). Phanomenologie der Munda-Religion, Freie University, Berlin.

[8] Sahoo, L. (May-2011). Kumar, "SocioEconomic profile of Tribal populations in Mayurbhanj and Keonjhar District", in Orissa Review ,Cuttack.

[9] Patnaik, S. (2010). "Educating the Tribal Children-The KISS Way", in Ota, A.B. , Bara, F. and Patnaik, K., eds., Dimension of Tribal Education in Odisha, Scheduled Castes and Scheduled Tribes Research and Training Institute, Government of Odisha, Bhubaneswar.

[10] Shastry, V.B. ( 2010). "Tribal Education Policy: Promises and Performances", in Ota, A.B., Bara, A.B. and Patnaik, K., eds., Dimension of Tribal Education in Odisha, Scheduled Castes and Scheduled Tribes Research and Training Institute, Government of Odisha, Bhubaneswar.

[11] Patnaik, N. (2005). Primitive Tribes of Orissa and Their Development Strategies, D.K. Print World (Pvt.), New Delhi.

[12] Ota, A.B., ed. (2014). Statistical Hand Book of Tribal Sub Plan (TSP) Blocks in Odisha, Scheduled Castes \& Scheduled Tribes Research and Training Institute, Government of Odisha, CRPF Square; Bhubaneswar.

[13] Nadeem Hasnain, (First Edition: 1991Reprint: 2016). Tribal India, Plaka Prakashana; Delhi. 
[14] Sahu, T. (2010).“Educational Complex for ST Girls Students in Low Female Literacy Pockets of Orissa", in Ota, A. B. , Bara, F., and Patnaik, K. eds., Dimensions of Tribal Education in Orissa, SCSTRTI, Bhubaneswar.

[15] Shastry, V.B. ( 2010). "Tribal Education Policy: Promises and Performances", in Ota, A.B., Bara, A.B. and Patnaik, K., eds., Dimension of Tribal Education in Odisha, Scheduled Castes and Scheduled Tribes Research and Training Institute, Government of Odisha, Bhubaneswar.

[16] Ota, A.B., Mall, A., Das, R.K. and Mohanty, S.C. (June \& December, 2010). "Education For Tribes of Orissa", in ADIVASI, Vol. 50, Issue No.1, Journal of Scheduled Castes and Scheduled Tribes Research and Training Institute, Bhubaneswar. Odisha, India.

[17] Singh, K. S. (2012). People of India: Odisha. Anthropological Survey of India, Seagull Books, Calcuttas.

[18] Mishra, R. (2011). Tribal Development-An Institutional Perspective, Bhubaneswar.

[19] Patnaik, Satyendra, (2010). "Educating the Tribal Children-The KISS Way", in A.B. Ota, F. Bara and K. Patnaik (eds.),Dimension of Tribal Education in Odisha, Scheduled Castes and Scheduled Tribes Research and Training Institute, Government ofOdisha, Bhubaneswar.

[20] KISS Annual Report 2015-2016, Kalinga Institute of Social Sciences, Bhubaneswar.

[21] Saren, G. (July 2013). "Impact of Globalizations on the Santals: A Study on Migration in West Bengal, India”, in International Journal of Humanities and Social Science Invention, Volume-2, Issuse-7.

[22] Dey, A. (June-2015). "Globalization and Change in Santhal Tribe at Paschim Medinipur (West Bengal. India)", in International Journal of Scientific Research, Vol. 4, Issue-6.
[23] Chowdhury, S.S. (2013). The Santal Women -A Study in Eastern India and Bangladesh, Kolkata.

[24] Padhi, S. K. (2009). "Primitive Santal Tribes of Orissa: Culture, Life \& Language" in S. Patnaik (ed.) Glimpses of Tribal Issues, New Delhi.

[25] Murmu, S. C. \& Dash, J. (June \& December 2012). "Nature-Based OLCHIKI and Santal Ethno-National" in A. B. Ota, (ed.), ADIVASI, Vol.52, No.1 \& 2, Odisha Government Press, Cuttack.

[26] Troisi, J. (2000). Tribal Religion Religious Beliefs and Practices Among the Santals, New Delhi.

[27] Statistical Profile of Scheduled Tribes In India 2013.

[28] Karua, S. C. (2014). Tribal Culture of Odisha-A Focus on the Santal, Baripada, Mayurbhanj.

[29] www. Planningcommission.nic.in

[30] Census of India, (2011). District Census Hand Book, Part XII-B, Series-22, Village and Town Wise Primary Census Abstract (PCA), Mayurbhanj, Odisha.

[31] Tribes of Odisha, At a Glance, Empowering the Tribals of Odisha, 2015, Bhubaneswar.

[32] Ota, A. B. \& Mohanty, S. C. eds. (2015). Demographic Profile of Scheduled Tribes in Odisha (1961-2011), SCSTRTI, Government of Odisha, Bhubaneswar.

[33] Chhatia, S. K. (2013). "Santali Language Movement in Mayurbhanj", B. K. Mallik \& Jayanti Dora (ed.), Utkal Historical Research Journal, Bhubaneswar, VolumeXXVI.

[34] Mohanta, B.K.(2015). "Invention of $\mathrm{Al}$ Chiki Script for Santali Language: An Attempt to Preserve an Endangered Tribal Dialect," in G.K.Bera\& K. J. SVD (ed.), Endangered Cultures and Languages in India, Delhi.

[35] Sahoo, L. K. (2012). "Tribal Language Movement and Development Intervention in Mayurbhanj District of Odisha" in A. B. 
Ota (ed.), ADIVASI, Vol-52, No.1 \& 2, Scheduled Castes \& Scheduled Tribes Research and Training Institute (SCSTRTI), Government of Odisha, Bhubaneswar.

[36] Tambslyche, M. C.(2013). "The Impact of Cultural Diversity and Globalization in Developing a Santal Peer Culture in Middle India," in EMIGRA Working Papers No. 46.

[37] Ota, A. B. \& Mohanty, S. C. eds., (June \& December 2010)."Education for Tribes of Orissa", in Adivasi, Scheduled Caste \& Scheduled Tribes Research and Training Institute (SCSTRTI), Government of Orissa, Bhubaneswar, Volume-50, Number-1.

[38] Padhy, K. C. (1998). Economic Development of Tribals Approach, Method and Strategy, New Delhi.

[39] Paul, S. K. \& Gupta, A., (2015). "The Changing Cultural Pattern among the Santals of Birbhum, West Bengal", in South Asian Anthropologist.

[40] Ota, A. B. \& Mohanty, R. P. eds., (2009). "Educational Polices, Programmes and Schemes, and Literacy Profile of Tribal Women", in Education of the Tribal Girl Child: Problems \& Prospects, Scheduled Castes \& Scheduled Tribes Research and Training Institute, Bhubaneswar.

[41] Andrabi, A. A. (2013). "Development of education of Scheduled Tribes in Jammu and Kashmir", in International Journal of Social Sciences Tomorrow (IJSST), Published by SPIRI (Society for Promoting International Research and Innovation), Vol-2, No. 4.

[42] Mishra, R. (2011).Tribal Development: An Institutional Perspective, Bhubaneswar.

[43] Mishra, B. (2010). "Impediments to Enlightenment: Perspective of Tribal Girls on Furthering Higher Education in ST Communities", in A. B. Ota, Florencia Bara \& K. Patnaik (eds.), Dimensions of Tribal Education in Orissa, Scheduled
Castes and Scheduled Tribes Research \& Training Institute, Government of Orissa Bhubaneswar.

[44] Tribal Education in Odisha in the Context of Education for All by 2000 AD: A State Paper, (1994). Published by Tribal Welfare Department, Government of Odisha, Bhubaneswar.

[45] KISS Annual Report (2015-2016). Kalinga Institute of Social Sciences, Bhubaneswar. 